\title{
Possible association of marine bacteria with paralytic shellfish toxicity of bivalves
}

\author{
Masaaki Kodama, Takehiko Ogata, Shigeru Sato, Setsuko Sakamoto \\ Laboratory of Marine Biological Chemistry, School of Fisheries Sciences, Kitasato University, Sanriku, Iwate 022-01, Japan
}

ABSTRACT: Significant amounts of paralytic shellfish toxins (PSP toxins) were detected in particles in the size fraction 0.45 to $5 \mu \mathrm{m}$ in seawater from Ofunato Bay, Japan, collected at a time when the toxicity of scallop increased in the absence of the causative organism Protogonyaulax tamarensis. Toxin in the same fraction was negligible when scallop toxicity was decreasing. PSP toxins were also detected in the bacterial fraction from cell-free cultured medium of $P$. tamarensis. Previously, we reported that Moraxella sp. isolated from $P$. tamarensis produces PSP toxins. About 17 and $60 \%$ respectively of bacteria in the seawater and the cultured medium of $P$. tamarensis reacted with anti-Moraxella sp. serum. These results suggest that PSP toxin-producing bacteria are present in the environmental water and are responsible for bivalve toxicity.

Paralytic shellfish toxins (PSP toxins) are potent neurotoxins produced by toxic dinoflagellates such as Protogonyaulax tamarensis (Schantz 1986). During blooms of such species, shellfish become toxic by ingesting them. However, we have previously observed that shellfish toxicity often also increases in the absence of $P$. tamarensis in Ofunato Bay, Japan (Ogata et al. 1982, Sekiguchi et al. 1989). In addition, we have found that low levels of PSP toxins are distributed widely in bivalves inhabiting toxic dinoflagellate-free waters (Ogata et al. 1989). These facts suggest the occurrence of other causative organism(s) of these toxins besides toxic dinoflagellates. Recently, we reported that a marine bacterium, Moraxella sp., isolated from P. tamarensis, produces PSP toxins (Kodama et al. 1988, Kodama et al. unpubl.). In the present study, we identified PSP toxins in particles of bacterial size separated from seawater during a period when bivalve toxicity increased in the absence of toxic dinoflagellates. PSP toxins were also detected in particles of similar size separated from cell-free cultured medium of $P$. tamarensis.

The abundance of Protogonyaulax tamarensis and scallop Patinopecten yessoensis toxicity were monitored at a station in Ofunato Bay, Iwate Prefecture, Japan, from February to December, 1988, in the same manner as described before (Ogata et al. 1982). Toxicity is expressed in mouse units (MU) where $1 \mathrm{MU}$ is the dose which kills a $20 \mathrm{~g}$ male mouse (ddY strain) in 15 min. As shown in Fig. 1, P. tamarensis appeared in
Fig. 1 Seasonal variation of scallop toxicity and the abundance of Protogonyaulax tamarensis in Ofunato Bay, Japan, 1988. Abundance of $P$. tamarensis is expressed as sum of cell number observed in $1 \mathrm{l}$ of each $2 \mathrm{~m}$ layer from surface to bottom

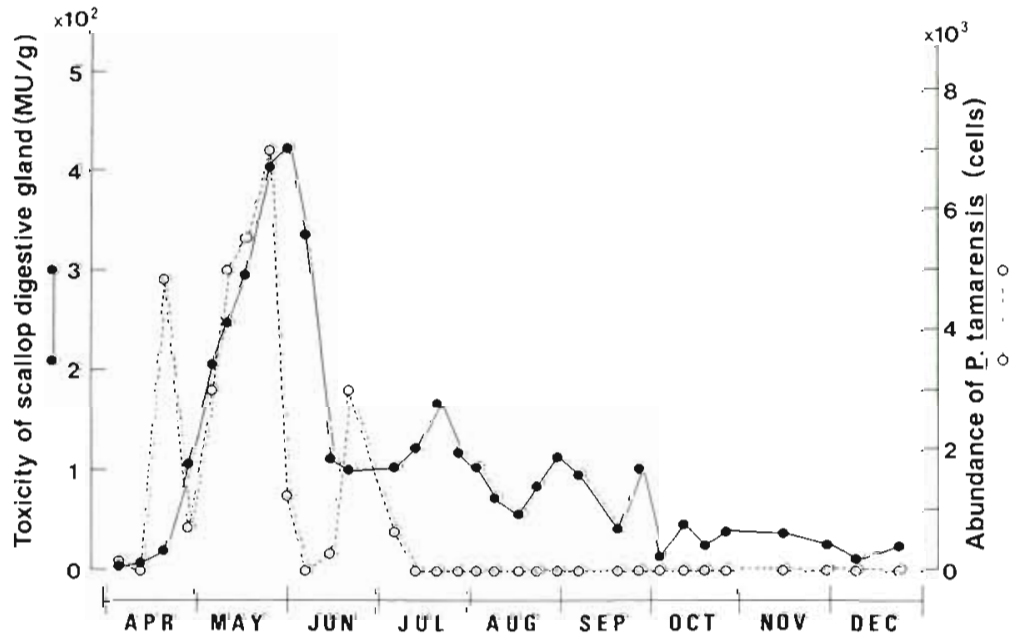

$0171-8630 / 90 / 0061 / 0203 / \$ 03.00$ 
April and disappeared completely at the beginning of July. Scallop toxicity increased with increase of $P$. tamarensis and decreased after disappearance of $P$. tamarensis. However, it increased again in the absence of $P$. tamarensis at the end of July. After peaks in August and September, scallop toxicity decreased gradually until December. A 1001 sample of seawater was collected on 24 and 29 July and on 20 December from the station. These were filtered through a $20 \mu \mathrm{m}$ sieve and through membrane filters with pore sizes of 5 and $0.45 \mu \mathrm{m}$, successively.

The particles, together with membrane filters, were homogenized with $\mathrm{HCl}$-acidified $80 \%$ ethanol by sonication for $2 \mathrm{~min}$ and centrifuged (10000 $\mathrm{g}, 10 \mathrm{~min})$. Residual toxin in the precipitate was extracted again. The supernatants were combined and evaporated to remove ethanol, defatted with dichloromethane, evaporated to dryness, and then dissolved in $2 \mathrm{ml}$ of distilled water. Each $10 \mu l$ aliquot of the extracts was analyzed by HPLC-fluorometric analysis (Oshima et al. 1987). Toxin amounts were calculated from peak heights and expressed as the sum of MU of each toxin component. The extracts were also tested for sodium channel blocking activity by tissue culture bioassay (Kogure et al. 1988, Sato et al. 1988).

Protogonyaulax tamarensis (OF84423D-3) was cultured in $2 \mathrm{l}$ of $\mathrm{T} 1$ medium at $15^{\circ} \mathrm{C}$ as reported previously (Ogata et al. 1987). The cells were harvested at the lateexponential phase by filtration using a 20 um sieve. The cell-free medium was then treated by membrane filters as described above. Extracts of particles trapped by membrane filters were analyzed as described above.

Antiserum against PSP toxin-producing Moraxella sp. was prepared by immunizing rabbit with washed and formalin-treated cells. Bacteria in seawater and cell-free cultured medium of Protogonyaulax tamarensis were examined for cross-reactivity with the antiserum.
Extracts from all fractions of the water collected in July showed peaks of PSP toxins in HPLC-fluorometric analysis. Fig. 2 shows the chromatograms of each fraction collected on 24 July. Most of the toxicity was concentrated into the 0.45 to $5 \mu \mathrm{m}$ fraction. A large peak corresponding to gonyautoxin (GTX) 1 was detected in the 0.45 to $5 \mathrm{um}$ fraction with small peaks corresponding to GTX 2,3 and 4. Trace amounts of saxitoxin (STX) and neoSTX were detected. A similar toxin profile was also observed in the extracts of the $20 \mu \mathrm{m}$ and 5 to $20 \mu \mathrm{m}$ fractions. However, the peaks were much smaller, suggesting that toxins in these fractions were contaminants from the 0.45 to $5 \mu \mathrm{m}$ fraction. The calculated toxin amount in the 0.45 to $5 \mu \mathrm{m}$ fraction was $61.8 \mathrm{MU}$ per $100 \mathrm{l}$, which is likely to be responsible for the increase in scallop toxicity. This fraction showed sodium channel blocking activity in neuroblast cell culture bioassay (Kogure et al. 1988). Assumed toxicity from the standard curve of STX in this method (Sato et al. 1988) was comparable to that from HPLC analysis (ca 50 MU per $100 \mathrm{l}$ ). A similar result was obtained from the seawater sample collected on 29 July. In contrast, the toxin content of the same fraction collected in December, when no Protogonyaulax tamarensis was observed and scallop toxicity was decreasing, was negligible (0.1 MU). PSP toxins were also detected in the same particle fraction obtained from cell-free cultured medium of $P$. tamarensis. In HPLC-fluorometric analysis, clear peaks of GTX 1, 2, and 3 and neoSTX appeared (Fig. 3). Faint peaks corresponding to GTX 4 and STX were also detected. This fraction also showed sodium channel blocking activity in neuroblast cell culture assay.

When the seawater collected in July and the cellfree cultured medium of Protogonyaulax tamarensis were inoculated onto agar plate (Marine Broth, Difco),

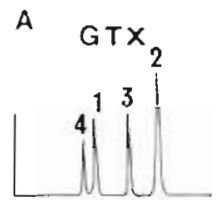

C

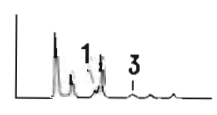

E

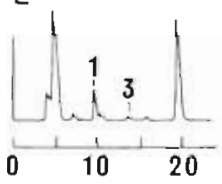

B

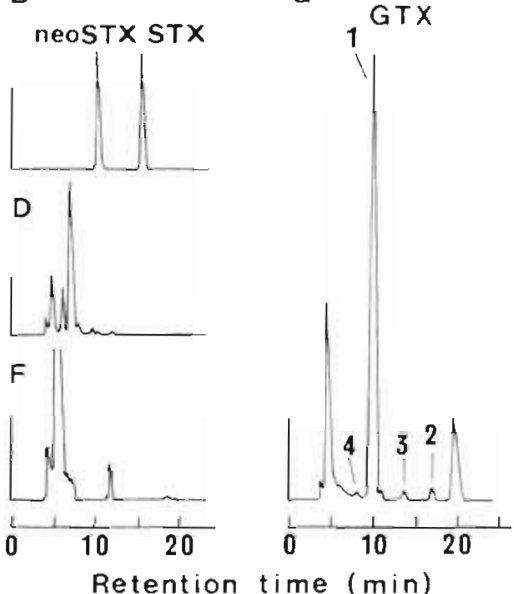

H

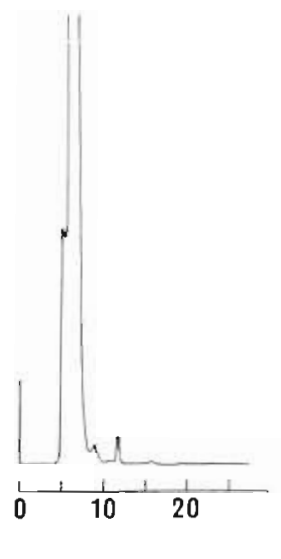

Fig. 2. HPLC-fluorometric analysis of the extract of each particle fraction from seawater Mobile phase for GTX fractions (A), (C), (E), (G): 2 mM 1-heptanesulfonic acid/10 mM phosphoric acid ( $\mathrm{pH}$ 7.2): mobile phase for STX frackons (B), (D). (F), (H): $2 \mathrm{mM}$ 1-heptanesulfonic acid/10 $\mathrm{mM}$ phosphoric acid/10\% acetonıtrile (pH 7.2). (A) GTX standards; (B) neoSTX and STX standards; (C) and (D) $>20 \mathrm{~km}$ fraction; $(E)$ and $(F) 5$ to $20 \mu \mathrm{m}$ fraction;

(G) and $(\mathrm{H}) 0.45$ to 5 um fraction 
A

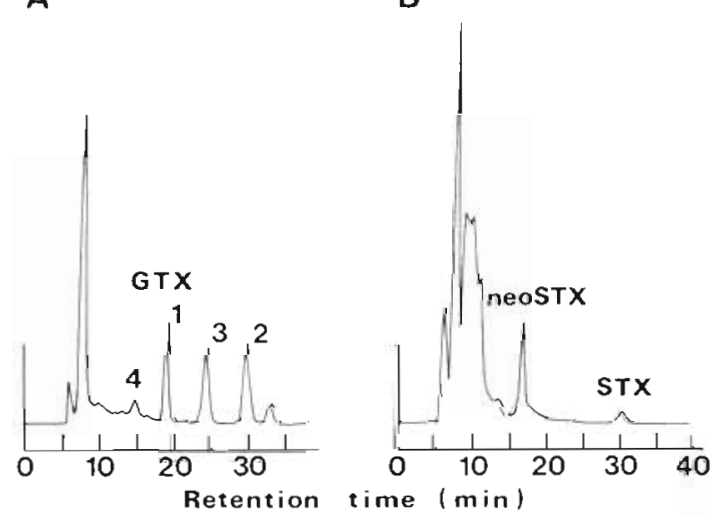

Fig. 3. HPLC-fluorometric analysis of the extract of 0.45-5 $\mu \mathrm{m}$ fraction from cultured medium of $P$. tamarensis. Mobile phase for GTX fraction (A) and STX fraction (B): refer to Fig. 2

$5.4 \times 10^{3}$ and $1 \times 10^{6}$ of bacterial colonies were observed in $1 \mathrm{ml}$, respectively. Of these, about $17 \%$ in the seawater and $60 \%$ in the cultured medium showed cross-reactivity with the anti-Moraxella sp., suggesting the occurrence of Moraxella sp. in these fractions. Previously, we reported that Moraxella sp. produces small amount of STX when grown in commercially available media (Kodama et al. 1988). Recently, we have found that toxin productivity of Moraxella sp. increases when grown in starved conditions and that main toxins produced under these conditions are GTXs, chiefly GTX 1 and 4 (Kodama et al. in press). From these findings, we concluded that PSP toxins found in the seawater or cultured medium of $P$. tamarensis originate from Moraxella sp. grown in nutrition-deficient conditions.

Nelinda et al. (1985) isolated extracellular bacteria from the cultured medium of various strains of Protogonyaulax tamarensis, cultured them in nutrient-rich media, and examined their toxin productivity. However, they did not detect any PSP toxins in the bacterial extracts. Toxin production of their isolates grown in nutrient-rich conditions might have been too low to be detected.

Under microscopic observation, we detected a small number of picoplankton in the 0.45 to $5 \mu \mathrm{m}$ fraction. However, particles in this fraction from cultured medium of Protogonyaulax tamarensis also showed the presence of PSP toxins, whereas no picoplankton were observed here. These facts show that marine bacteria in these fractions possess PSP toxins.

It has been a general belief that dinoflagellates are the primary producers of PSP toxins and responsible for shellfish toxicity. Present results however show that the bacterial fraction of seawater possesses a significant amount of PSP toxins (61.8 MU per 100 l). These results suggest that PSP toxin-producing bacteria as well as toxic dinoflagellates are responsible for the toxicity of bivalves. In a previous paper (Ogata et al. 1989), we identified PSP toxins in the freshwater bivalve Corbicula sandai as well as in the marine bivalve Septifer vergatus collected from water known to be free of toxic dinoflagellates, and suggested the presence of unknown causative organism(s) responsible for PSP toxins in bivalves. These findings support the possible association of bacteria with paralytic shellfish toxicity in bivalves.

As described above, scallop toxicity often increased in the absence of Protogonyaulax tamarensis. Interestingly, however, no significant increase of scallop toxicity was observed either just before or a long period (such as $1 \mathrm{yr}$ ) after a $P$. tamarensis bloom in the monitoring survey from 1981 to 1988 (Sekiguchi et al. 1989). A bloom of toxic dinoflagellates would induce the increase of toxin-producing bacteria in the environment enough to be responsible for significant increase of bivalve toxicity.

Acknowledgements. This work was partly supported by grants from Ministry of Education, Science and Culture of Japan, Ministry of Agriculture, Fisheries and Forestry of Japan, and Kaiun Mishima Foundation.

\section{LITERATURE CITED}

Kodama, M., Ogata, T, Sato, S. (1988). Bacterial production of saxitoxin. Agric. biol. Chem. 52: 1075- 1077

Kodama, M. Ogata, T., Sakamoto, S., Sato, S., Honda, T., Miwatani, T (in press). Production of paralytic shellfish toxins by a bacterium Moraxella sp. isolated from Protogonyaulax tamarensis. Toxicon

Kogure, K., Tamplin, M. L., Simidu, U., Colwell, R. R. (1988). A tissue culture assay for tetrodotoxin, saxitoxin and related toxins. Toxicon 26: 191-197

Nelinda, M., Dimanlig, V., Taylor, F. J. R. (1985). Extracellular bacteria and toxin production in Protogonyaulax species. In: Anderson, D. M., White, A. W. Baden, D. G. (eds.) Toxic dinoflagellates. Elsevier, New York, p. 103-108

Ogata, T., Ishimaru, T., Kodama, M. (1987). Effect of water temperature and light intensity on growth rate and toxicity change in Protogonyaulax tamarensis. Mar. Biol. 95: $217-220$

Ogata, T., Kodama, M., Fukuyo, Y., Inoue, T., Kamiya, H., Matsuura, F., Sekiguchi, K., Watanabe, S. (1982). The occurrence of Protogonyaulax spp. in Ofunato Bay, in association with the toxification of the scallop Patinopecten yessoensis. Bull. Jap. Soc. scient. Fish. 48: 563-566

Ogata, T., Sato, S., Kodama, M. (1989). Paralytic shellfish toxins not associated with dinoflagellates. Toxicon 27 : $1241-1244$

Oshima, Y., Hasegawa, H., Yasumoto, T., Hallegraeff, G., Blackburn, S. (1987). Dinoflagellate Gymnodinium catenatum as the source of paralytic shellfish toxins in Tasmanian shellfish. Toxicon 25: 1105-1111

Sato, S., Ogata, T., Kodama, M., Kogure, K. (1988). Determination of paralytic shellfish toxins by neuroblast culture assay. In: Aibara, K., Kumagai, S., Ohtsubo, K, Yoshizawa, T (eds.) Proc. of the Japanese Association of Mycotoxicol- 
ogy, Suppl. No. 1, IUPAC' 88 and ICPP' 88 , Mycotoxins and Phycotoxins. the Japanese Association of Mycotoxicology, Tokyo, p. 3-4

Schantz, E. J. (1986). Chemistry and biology of saxitoxin and related toxins. Ann. N.Y Acad. Sci. 479: 15-23

Sekiguchi, K., Ingoguchi, N., Shimizu, M., Saito, S., This note was presented by Professor S. Puiseux-Dao, Paris, France
Watanabe, S., Ogata, T., Kodama, M., Fukuyo, Y (1989). Occurrence of Protogonyaulax tamarensis and shellfish toxicity in Ofunato Bay from 1980-1986. In: Okaichi, T., Anderson, D. M., Nemoto, T. (eds.) Red tides: biology, environmental science, and toxicology. Elsevier, New York, p. 399-402

Manuscript first received: August 15, 1989

Revised version accepted: December 20, 1989 